\title{
An Exploratory of Marketing Communication Strategy of Dietary Supplement Products on Social Media in Thailand: Preliminary findings
}

\author{
Pawonpol Sornrabeab $^{1 *}$, Suttanipa Srisai ${ }^{2}$, Jantima Kheokao ${ }^{3}$ and Piriya Phovijit ${ }^{4}$ \\ ${ }^{1}$ Student at D.Com.Arts, Marketing Communication, University of the Thai Chamber of Commerce, Thailand \\ ${ }^{2}$ Asst Prof. Suttanipa Srisai, a program director of M.Com.Arts, Marketing Communication at University of the \\ Thai Chamber of Commerce, Thailand \\ ${ }^{3}$ Assoc Prof. Jantima Kheokao, a program director of D.Com.Arts, Marketing Communication at University of \\ the Thai Chamber of Commerce, Thailand \\ ${ }^{4}$ Ph.D. Piriya Phovijit, a managing director of Entertainment media company, Comedy Line Co., Ltd. Bangkok, \\ Thailand
}

\begin{abstract}
.
The purpose of the study was to investigate marketing communication strategy of dietary supplement products on social media in Thailand. To study how dietary supplement product/brand use marketing communication strategies and tools to make itself outstanding in the market. The study was a qualitative research, to interview with 8 key informants who are involving in the market field; 1 product owner, 1 marketing manager, 1 online marketer and 5 product sales representatives on social media. Common results of the interview showed that every key informant concerning about 1. 'differentiating', to push their product outstanding in the market, being in mind of customer and being first of choice. 2. 'reinforce/reminding', high frequency of advertising on social media should be posted on social media into the right time, the right channel and the right person. 3. 'informing', by information pushing and healthbenefit claim should be more concern. 4. 'persuading', by using attractive cues such as picture, celebrity influencer, word-of-mouth, product reviewing by user and customer relationship management also have been used in the market. Conclusion of the study, this study is to find out marketing communication strategy on dietary supplement product on social media in Thailand by studying on the sender side (product/brand). They used marketing communication strategy to push the product into market but some of strategy (some advertising, messages, picture, health-benefit claim etc.) are not following by the regulation and leading to health-related misunderstanding and causing serious health harming. This study would be useful for the further study for preventing an illegal marketing communication on dietary supplement product on social media in Thailand.
\end{abstract}

Keywords: Marketing communication, Marketing communication strategy, Marketing communication element, Dietary supplement product and Health product advertising. 


\section{Introduction}

The share of dietary supplement market in Thailand accounted to USD 1,682 million in 2016 (Kasikornresearch, 2017). The growth of the dietary supplement market has been driven by the country's overall social and economic climate and the changing lifestyles of the consumers (Angsukaset, 2002). They are looking for ways to stay healthy in the long run and be more cautious with their dietary, take more exercise and use nutritional supplements (Euromonitor international, 2019). Research has shown that people who are health conscious will opt for the most vitamin and mineral supplements (Wangcharoen, Amormlerdpison \& Mengumphan, 2013).

What is dietary supplement? Dietary supplement is intended to supplement the diet for the prospective consumer health promotion benefits which contains nutrients or other substances as elements, in form of pill, tablet, capsule, powder, flake or other form which is not in form of conventional food (Thailand Food Act of B.E. 2522, 2013). In each country, the dietary supplement was called in the different way, in USA calls 'Dietary Supplements', in Canada calls 'Natural Health Products', in Australia calls 'Complementary Medicines', in China calls 'Health Food Products' in EU and WHO call 'Food Supplements' (Mookajornphan, 2008). In term of Thai law, the dietary supplement is regulated by Thai FDA as a 'food' that cause physiological changes. So, in every process of manufacturing are regulated strictly, such as production process, quality control, importation of ingredients, distribution, labeling, healthrelated claims and advertising must be made under the Thai FDA approval. The healthrelated claim of dietary supplement must be accordance with Ministry of Public Health's notification. The Thai FDA does not allow dietary supplement product to describe of healthrelated conditions on labeling, every message, picture, movie on broadcasting, radio, newspaper, printed ads and any channel of advertising must be considered and approved by regulator (Thai FDA) before publishing (Thailand Food Act of B.E. 2522, 2013).

In the situation of dietary supplement market Thailand, the number of online consumer purchases dietary supplement via social media channel is increasing (Dejprapasorn, 2015). Many dietary supplement products/brands are developing competitive strategies, marketing strategies (Srimanee, Sriwanat and Sanson, 2017) and marketing communication strategies for advantages (Angsukaset, 2002). Marketing communication is crucial element to build profitable customer, retailer and other stakeholder relationships (Kotler \&Armstrong, 2008) and for more effective marketing communication is necessary the consistency among all communication messages by the use of highly consistent set of message themes and visuals that deliver to target audiences perception (McGrath, 2005), and the dietary supplement products/brands also use marketing communication strategy to make customer getting awareness, knowledge, belief, attitude, purchase intention and finally purchase the product (Angsukaset, 2002). An individual purchase decision depends on four psychological factors such as persuasion, awareness, learning and belief/attitude (Kotler \&Armstrong, 2014) and the psychological factor for purchase decision of Thai herbal supplement is persuasion and awareness (Harnkaipong, 2011). All communication messages are information flow (marketing flow) that can be represented as 
a network whose sole purpose is the satisfaction of customer needs and wants (Bowersox and Morash, 1989).

In the legal restriction and the intense competition of dietary supplement product in Thailand, competing by both international and local players. While international players have advantages in many aspects, such as innovations, know-how, research and financial resources, and the local players are looking to establish it to be outstanding in mind of customers. In this study, the purpose is to explore marketing communication strategies of local dietary supplement brand, to investigate the strategy used by focusing on only social media channel.

\section{Literature review}

Marketing communication is crucial element to build profitable customer, retailer and other stakeholder relationships (Kotler and Armstrong, 2008). There are five main marketing communication tools: advertising, sale promotion, personal selling, public relations and direct marketing (see table 1) and there are media in which be used to deliver messages to target audiences. The appropriate mix of these tools and the choice of media were variations reflecting particular brand (Fill \&Jamieson, 2006).

Table 1: Marketing communication tools

\begin{tabular}{|l|l|l|}
\hline \multicolumn{2}{|c|}{ Marketing communication tools } \\
\hline & \multicolumn{1}{|c|}{ What this can communicate } & \multicolumn{1}{c|}{ Example } \\
\hline Advertising: & Identity & Clearly stated valuation \\
\hline Sale promotion: & Value & Buy 2, get 1 free offer \\
\hline Personal selling: & Attention and concern & Problem resolved \\
\hline Public relations: & Expertise & Comment on social issue \\
\hline Direct marketing: & Personalized offer & Follow-up offer \\
\hline
\end{tabular}

Source: Richard J. Varey, 2000 (Base on Kotler, 2000)

Fill and Jamieson (2006) demonstrated that communication plays an important role in the marketing flow that can assume four main roles/elements of marketing communication; 1) to differentiate; 2) to remind/reinforce; 3) to inform; and 4) to Persuade. They offer a simple acronym DRIP for remembering the uses of marketing communication. (see table 2) 
Table 2: DRIP elements of marketing communication

\begin{tabular}{|l|l|}
\hline \multicolumn{2}{|c|}{ DRIP elements of marketing communication } \\
\hline Differentiating: & $\begin{array}{l}\text { trying to exclude competing products from consumer decision-making by making } \\
\text { your own more attractive and closer match to their needs }\end{array}$ \\
\hline Reinforce/reminding: & $\begin{array}{l}\text { trying to ensure that when options for consumption are being assessed, your product } \\
\text { is included }\end{array}$ \\
\hline Informing: & $\begin{array}{l}\text { providing data into the consumer's mindful and appreciative thought processes to } \\
\text { ensure that your product is considered as an attractive option in consumption }\end{array}$ \\
\hline Persuading: & \begin{tabular}{l} 
effort to induce desire favorable behavior from the consumer \\
\hline
\end{tabular}
\end{tabular}

\section{Source: Fill and Jamieson, 2006}

Marketing mix is a tool used to determine the desired responses from target market (Kotler, 2000) and can be classified into four broad group, 4Ps of marketing: product, price, place and promotion (McCarthy and Perreault, 1996). Marketing mix is the set of marketing tools that the marketing manager uses to pursue their marketing objectives in the target market (Kotler, 2000), and marketing mix is a system of communication that emphasize the interlocking nature of the various aspects of tangibles and intangibles that 'say something' to consumers/buyers, so we can think of the marketing mix elements as communicator, and the communicative effect from the consumer/buyer perspective and highlights the manager's intention (Richard J. Varey, 2000). (see table 3)

Table 3: Communicative aspects of the marketing situation that can be decided by the marketing manager

\begin{tabular}{|c|c|c|c|}
\hline The offering & What this can communicate & The offering & What this can communicate \\
\hline \multicolumn{2}{|l|}{ Product mix } & \multicolumn{2}{|l|}{ Place mix } \\
\hline Variety & Personality & Channels & Convenience and status \\
\hline Quality & Integrity & Coverage & Availability \\
\hline Design & Taste & Assortments & Choice \\
\hline Features & Flexibility & Locations & Convenience and status \\
\hline Brand name & Assurance & Inventory & Availability \\
\hline Packaging & Protection and care & Transport & Availability \\
\hline Sizes & Consideration & \multicolumn{2}{|l|}{ Promotion mix } \\
\hline
\end{tabular}




\begin{tabular}{|l|l|l|l|}
\hline Services & Support & Advertising & Identity \\
\hline Warranties & Peace of mind & Publicity & Expertise \\
\hline Returns & Confidence & Sale promotion & Value \\
\hline Price mix & Expectations of quality & Personal selling & Attention and concern \\
\hline Cost of product & Value for money & & \\
\hline Discounts & Affordability & & \\
\hline Payment period & Cost & & \\
\hline Credit terms & & & \\
\hline
\end{tabular}

Source: Richard J. Varey, 2000 (Base on Kotler, 2000; Dibb et al., 1999)

Kasikorn Research Center (2017) showed a desire of dietary supplement, classified by target audience as following below; older desired and millennials desired. (see table 4)

Table 4: Desire of dietary supplement classified by target audience

\begin{tabular}{|l|l|}
\hline \multicolumn{1}{|c|}{ Older desired } & \multicolumn{1}{|c|}{ Millennials desired } \\
\hline $\begin{array}{l}\text { Type of product } \\
\text { 1. For general health maintenance; memory } \\
\text { enhancement/digestion }\end{array}$ & $\begin{array}{l}\text { Type of product } \\
\text { 1. For general health maintenance; brain function } \\
\text { enhancement/eye health/gain }\end{array}$ \\
\hline $\begin{array}{l}\text { improvement/blood circulation/sleep } \\
\text { aids/fatigue/eye health/bone } \\
\text { healing/muscle function and teeth etc. } \\
\begin{array}{l}\text { For prevention and treatment; } \\
\text { diabetes/hypertension/heart disease and } \\
\text { hyperlipidemia etc. }\end{array}\end{array}$ \\
\hline
\end{tabular}

Source: Kasikorn Research Center (2017)

\section{Objective of the study}

To investigate marketing communication strategies of dietary supplement products on social media in Thailand

\section{Research Methodology}

This qualitative research investigated marketing communication strategies focusing on how dietary supplement product /brand communicate its strategies to target audiences on social media. We collected data by semi-structured interview with eight key informants who are involving in the field of dietary supplement market, product owner, marketing manager, online marketer and product sales representative who are strategy maker and close to customer on 
social media. Semi-structured interview enables the researchers to get rich information and insight of the product/brand's thought (Mohajan, 2018) and get understand on the strategy they used in the current intense competition.

Key informants considered by the type of the product (see table 4) were interviewed as follows.

Key informant 1 (K1): Product owner of 'weight loss product'

Key informant 2 (K2): Marketing manager of 'weight loss product'

Key informant 3 (K3): Online marketer of 'weight loss product'

Key informant 4 (K4): Product sale representative of 'detoxification product'

Key informant 5 (K5): Product sale representative of 'gain muscle product'

Key informant 6 (K6): Product sale representative of 'skin-health product'

Key informant 7 (K7): Product sale representative of 'reducing hyper lipid product'

Key informant 8 (K8): Product sale representative of 'bone healing product'

We did a semi-structured interview with 8 key informants by face-to-face interview and telephone interview. We used an interview guideline about marketing communication strategy we created. The interview guideline was determined by the scope of the literature review (DRIP elements of marketing communication, marketing communication tools and marketing mix). And the result of the study is following.

\section{Results}

Finding revealed that marketing mix was heavily used to communicate dietary supplement product /brand to the customers. In product mix, it was found that sizes/amount of the product was used most (7 key informants), followed by quality and brand name (6 key informants) and return of the product was the least use (1 key informant), respectively. Cost of product/price was used by most key informants (7) for price mix. In place mix, both channel and transport were used heavily. All promotion mix was used among eight key informants. Details were shown in Table 5. 


\section{SOCIAL SCIENCES IN THE 21ST CENTURY}

Table 5: Marketing mix used by the key informants

\begin{tabular}{|c|c|c|c|c|c|c|c|c|c|}
\hline \multicolumn{9}{|c|}{ Marketing communication tools } & \multirow[b]{2}{*}{ total } \\
\hline Key informants & $\mathrm{K} 1$ & $\mathrm{~K} 2$ & K3 & K4 & K5 & K6 & K7 & K8 & \\
\hline \multicolumn{9}{|l|}{ Product mix } & \\
\hline Variety & $\square$ & $\square$ & & & & & & & 2 \\
\hline Quality & $\square$ & $\square$ & & & $\square$ & $\square$ & $\square$ & $\square$ & 6 \\
\hline Design & $\square$ & $\square$ & & & & & & & 2 \\
\hline Brand name & $\square$ & $\square$ & $\square$ & $\square$ & $\square$ & $\square$ & & & 6 \\
\hline Packaging & $\square$ & $\square$ & & & & & & & 2 \\
\hline Sizes/amount & $\square$ & $\square$ & & $\square$ & $\square$ & $\square$ & $\square$ & $\square$ & 7 \\
\hline Warranties & $\square$ & $\square$ & & & $\square$ & & & & 3 \\
\hline Return & & & & & & & & & 1 \\
\hline \multicolumn{10}{|l|}{ Price mix } \\
\hline Cost of product/price & $\square$ & $\square$ & & $\square$ & $\square$ & $\square$ & $\square$ & $\square$ & 7 \\
\hline Discounts and allowance & $\square$ & $\square$ & & & & & & & 2 \\
\hline \multicolumn{10}{|l|}{ Place mix } \\
\hline Channels & $\square$ & $\square$ & $\square$ & $\square$ & $\square$ & $\square$ & $\square$ & $\square$ & 8 \\
\hline Transport & $\square$ & $\square$ & & $\square$ & $\square$ & $\square$ & $\square$ & $\square$ & 7 \\
\hline \multicolumn{10}{|l|}{ Promotion mix } \\
\hline Advertising & $\square$ & $\square$ & $\square$ & $\square$ & $\square$ & $\square$ & $\square$ & $\square$ & 8 \\
\hline
\end{tabular}




\begin{tabular}{|l|c|c|c|c|c|c|c|c|c|}
\hline Sale promotion & $\square$ & $\square$ & $\square$ & $\square$ & $\square$ & $\square$ & $\square$ & $\square$ & 8 \\
\hline Personal selling & $\square$ & $\square$ & $\square$ & $\square$ & $\square$ & $\square$ & $\square$ & $\square$ & 8 \\
\hline Public relation & $\square$ & $\square$ & $\square$ & $\square$ & $\square$ & $\square$ & $\square$ & $\square$ & 8 \\
\hline Direct marketing & $\square$ & $\square$ & $\square$ & $\square$ & $\square$ & $\square$ & $\square$ & $\square$ & 8 \\
\hline
\end{tabular}

According to DRIP elements of marketing communication, for K1 and K2 (product owner and marketing manager of weight loss product) concerned all of DRIP elements. For 'differentiating', they said "...every product has life cycle, they have to think of creating new product and push it into target needs...". For 'reinforce/reminding', K1 and K2 concerned about '... being in mind of customer' and 'being first choice' by using a high frequency of advertising, public relation and information push...". For 'informing', K1 and K2 concerned about details and information, they said "...under the legal restriction of supplement advertising in Thailand, the information about health-benefit claim should be more concern especially about weight loss product...".

For 'persuading', K1 and K2 are very concentrated, they said “...because of the legal restriction they have to create an attractive strategy such as ads design, packaging design, and celebrity influencer...”. For K3 (online marketer of weight loss product) concerned about 'reminding' by using high frequency of advertising, $\mathrm{K} 3$ said “... an advertising should be posted on social media into the right time, the right channel and the right person...". And about 'persuading', K3 focused on message and picture strategy, K3 said “...a short word is more impact than long sentence and picture is more attractive than word...". For K4 - K8 (product sale representative), they all concerned on every element of DRIP especially 'persuading'.

K4 (detoxification/liver improvement product) said "he has to study about the product details and provoked customer's desired by pushing information of liver dysfunction especially to heavy drinker". K5 (gain muscle product) said "a picture of smart guy with beautiful muscle is most attractive for targets and fitness trainer is a good influencer, and challenge activity (progress of muscle building) was used to motivate target audiences". K6 (skin-health product) said "word-of-mouth is most powerful", "the result of the product (getting whitening skin) is attractive to new target" and "celebrity influencer is an important magnet" and "product reviewing by user is also credible”. K7 (reducing hyper lipid product) and K8 (bone healing product) both products are for elderly, they have to communicate into two group audience, one group for elderly themselves and another group for elderly caregiver. K7 and K8 said "wordof-mouth and psychological strategy are most powerful to them and customer relationship management makes them more loyalty". 
Table 6: DRIP element of marketing communication

\begin{tabular}{|l|c|c|c|c|c|c|c|c|}
\hline \multicolumn{7}{|c|}{ DRIP elements of marketing communication } \\
\hline \multicolumn{1}{|c|}{ Key informants } & K1 & K2 & K3 & K4 & K5 & K6 & K7 & K8 \\
\hline Differentiating & $\square$ & $\square$ & & $\square$ & $\square$ & $\square$ & $\square$ & $\square$ \\
\hline Reminding/reinforce & $\square$ & $\square$ & $\square$ & $\square$ & $\square$ & $\square$ & $\square$ & $\square$ \\
\hline Informing & $\square$ & $\square$ & & $\square$ & $\square$ & $\square$ & $\square$ & $\square$ \\
\hline Persuading & $\square$ & $\square$ & $\square$ & $\square$ & $\square$ & $\square$ & $\square$ & $\square$ \\
\hline
\end{tabular}

\section{Discussion}

The findings revealed that the dietary supplement product/brand concerned about marketing mix and used marketing communication strategies to push a product to the market. On product attribute, they concerned in every aspect, a quality of product and building brand name are very important task for the owner and manager. Under the legal restriction of dietary supplement product in Thailand, an intangible value has been used for communication strategy to make customer getting awareness, knowledge, belief and attitude. On pricing aspect, they also gave an attention to determine a price which represented a product value on customer seeing. On placing aspect, social media is a medium to connect and engage between product/brand and customers, the dietary supplement product is a product that needs more information to be given to the customer. Product/brand used social media channel (inbox message) for customer relationship management, to follow up a result of product usage and push continues buying. On promotion aspect, all of marketing communication tools have been used to communicate to customers. According to DRIP elements of marketing communication (Fill and Jamieson, 2006), the product owner and marketing manager concerned about 'differentiating', to push their product to be outstanding in the market, being in mind of customer and being first of choice. While product sales representative, they were too close with customers. They more concerned about 'informing' and 'persuading', by information pushing, attractive cues like picture, celebrity influencer, word-of-mouth, product reviewing by user and customer relationship management also have been used in the market. While online marketer concerned about 'reinforce/reminding', high frequency of advertising should be posted on social media into the right time, the right channel and the right person. 


\section{Conclusion}

This study is a preliminary study, to find out marketing communication strategy on dietary supplement product on social media in Thailand by studying on the sender side (product/brand). In the intense competition and the legal restriction, product/brand used marketing communication strategy to push the product into market but some of strategy (some advertising, messages, picture, health-benefit claim etc.) are not following by the regulation and leading to health-related misunderstanding and causing serious health harming. This study would be useful for the further study for preventing an illegal marketing communication on dietary supplement product on social media in Thailand.

\section{Acknowledgment}

For this study I would like to express my sincere gratitude to my two advisors Asst Prof. Suttanipa Srisai and Assoc. Prof. Jantima Kheokao who always believe in me and always be kind to me. Thanks for their patience, motivation and immense knowledge. My special thanks to Dr.Piriya Phovijit who are always supporting me for everything, and he is person who are also believe in me and push me to the Ph.D journey. Last but not least, thank you to all of my key informants in this study; you are a big part of this. Thank to you all.

\section{References}

Angsukaset, K. (2002). Kon la yut kan sue san kan ta lad pha lit ta phan serm ar han [Marketing communication strategy of dietary supplement product], Master thesis in Journalism and Mass Communication, Thammasat university. Bangkok.

Bowersox, D. J. \& Morash, E. A. (1989). The integration of marketing flows in channels of distribution, European Journal of Marketing, 23(2), 58-67.

Dejprapasorn, N. (2015). Pat jai tee mee phon tor kan tad sin jai sue pha lit ta phan serm ar han tang in ter net [Factors affecting online purchase decisions for dietary supplements in Thailand], Independent study in Thammasat Business School, Thammasat university. Bangkok.

Euromonitor international. (2019). Dietary Supplements in Thailand. [Online]. Available: https://www.euromonitor.com/dietary-supplements-in-thailand/report

Fill, C. \& Jamieson, B. (2006). Marketing Communication, Edinburgh Business School HeriotWatt University. Edinburgh, UK.

Harnkaipong, P. (2011). Pat jai tang jit ta vit ta ya lae pat jai tang pha lit ta phan tee song phon tor kan bor ri phok ar han serm jak sa moon pai thai khong phoo bor ri phok naik khate kung thep ma ha na korn [Psychological factors and product that affecting the consumption of Thai herb food consumers in Bangkok], Independent study in School of Business Administration, Bangkok university. Bangkok.

Kasikorn Research Center. (2017). K SME analysis. Kasikorn Bank Thailand. [Online]. Available: 
https://kasikornbank.com/th/business/sme/KSMEKnowledge/article/KSMEAnalysis/D ocuments/HealthyProduct.pdf

Kotler, P. (2000). Marketing Management, Millennium Edition. Pearson Custom Publishing, Boston, MA.

Kotler, P. \& Armstrong, G. (2008). Kotler and Armstrong Marketing Communication. [Online]. Available: https://www.ukessays.com/essays/marketing/kotlerandarmstrongs-marketing-communication-marketing-essay.php

Kotler, P. \& Armstrong, G. (2014). Principle of marketing (15 ${ }^{\text {th }}$ ed.). Upper Saddle River, NJ: Pearson Education.

McCarthy, E., J. \& Perreault, W., D. (1996). Basic Marketing: A Global-Managerial Approach. 13rd ed. Richard D Irwin, Burr Ridge, IL.

McGrath, J. M. (2005). A pilot study testing aspect of the integrated marketing communications concept, Journal of Marketing Communications, 11(3), 191-214.

Ministerial regulations and Notification of the Ministry of Public Health Thailand. (2013). Food Act B.E. 2522. vol. 293, p. 376-379.

Mohajan, H., K. (2018). Qualitative Research Methodology in Social Sciences and Related Subjects, Journal of Economic Development, Environment and People, 7(1), 23-48.

Mookajornphan, D. (2008). Dietary supplement: The fact you should know, Quality of life, vol.14, no.123, 90-93.

Srimanee, N., Sriwanat A. and Sanson, R. (2017). Rup bab kon la yut kan ta lad thu la kit pha lit ta phan serm ar han nai pa thed thai [Marketing strategies model of supplementary food products business in Thailand], Doctor of Philosophy in Social Sciences Association Ramkhamhaeng University", 7(2), 75-89.

Varey, R., J. (2002). Marketing Communication Principles and Practice. Routledge, London, p. 135.

Wangcharoen, W., Amornlerdpison, D. \& Mengumohan, K. (2013). Factors influencing dietary supplement consumption: A case study in Chiang Mai. Maejo International Journal of Science and Technology, 7(1), 155-165. 